Sains Malaysiana 49(9)(2020): 2281-2291

http://dx.doi.org/10.17576/jsm-2020-4909-25

\title{
Crack-Healing Investigation in Asphalt Mixture with Modified Thermoplastic- Bitumen Composite
}

(Kajian Pemulihan-Keretakan dalam Campuran Asfalt dengan Termoplastik Terubah Suai - Komposit Bitumen)

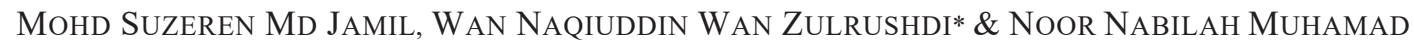

\begin{abstract}
This study aims to investigate the crack-healing of asphalt mixture by induction heating of bitumen-thermoplastic binder. This system employs a heterogeneous mixture, in which different percentages $(2,4,6$, and $8 \%$ by weigh) of thermoplastic healing agent (polyethylene (PE) and polypropylene (PP)) dissolve with the bitumen, respectively. Healing was achieved by heating the fractured asphalt composite to a specific temperature; in which heterogeneous blend has undergone random molecule diffusion and volumetric thermal expansion of healing agent within the matrix. The thermal properties in the bitumen-thermoplastic were characterized by means of dynamic mechanical thermal analysis (DMTA); in which the glass transition temperature ( $T$ ) has been used as a reference for the healing process. The FTIR shows no chemical reaction between bitumen and thermoplastic. Three-point bending test was conducted to demonstrate details crack-healing capability in asphalt composite. The results show that $6 \%$ of PE and PP to the mixture of bitumenthermoplastic has the highest tensile strength. The percentage of recovery was also measured through the healing cycle process using a three-point bending test. Overall, within the third healing cycle, asphalt composite with modified bitumen (with PP or PE) shows $98-55 \%$ of healing recovery. The best percentage recovery is using bitumen-PP mixture with a ratio of 94:6. The crack-healing process was also proven through the surface and cross-section asphalt morphology analyses using optical microscopy and scanning electron microscope (SEM).
\end{abstract}

Keywords: Asphalt; bitumen-thermoplastic; crack healing; healing agent

ABSTRAK

Fokus kajian ini adalah untuk mengkaji kesan pemulihan keretakan bagi campuran asfalt melalui proses pemanasan pada pengikat bitumen-termoplastik. Sistem ini menggunakan campuran heterogen; agen pemulihan termoplastik (polietilena (PE) dan polipropilena (PP)) dengan peratusan yang berbeza $(2,4,6$ dan $8 \%$ keseluruhan berat) dicampurkan bersama bitumen. Pemulihan dapat dicapai melalui pemanasan komposit asfalt yang mengalami keretakan pada suhu tertentu; campuran heterogen ini akan melalui proses penyebaran molekul secara rawak dan pengembangan volumetrik termal agen pemulihan dalam matriks. Sifat termal untuk bitumen-termoplastik dapat dicirikan melalui analisis haba mekanik dinamik (DMTA); suhu peralihan kaca ( $T_{\text {g }}$ telah digunakan sebagai rujukan bagi proses pemulihan. FTIR menunjukkan tiadanya interaksi kimia antara bitumen dan termoplastik. Ujian lenturan tiga titik dijalankan untuk membuktikan keupayaan pemulihan retak dalam komposit asfalt. Keputusan kekuatan tegangan yang tertinggi ditunjukkan bagi campuran bitumen-termoplastik dengan 6\% PE atau PP. Peratusan pemulihan juga diukur melalui proses kitaran pemulihan menggunakan ujian lenturan tiga titik. Secara keseluruhan, komposit asfalt dengan bitumen yang diubah suai (dengan PP atau PE) menunjukkan 98-55\% pemulihan keretakan berdasarkan tiga kitaran pemulihan. Peratusan pemulihan yang terbaik dapat dicapai dengan menggunakan campuran bitumen-PP dengan nisbah 94:6. Proses pembaikan retak juga telah dibuktikan melalui analisis morfologi asfalt permukaan dan keratan rentas menggunakan mikroskop optik dan mikroskopi elektron pengimbasan (SEM).

Kata kunci: Agen pemulihan; asfalt; bitumen-termoplastik; pembaikan retak

\section{INTRODUCTION}

Nowadays polymers are becoming increasingly important and widely applied in our daily lives. We can see through the polymer industries such as textiles, paints, electronics, tires, and many others are growing rapidly in the world.
This is because polymers can replace almost all the natural materials, and some are difficult to find.

As the most important material for pavement construction, asphalt has always been valued. The asphalt composite is a multiphase dispersion system, which is 
composed of mixes aggregate, sand, and binder. This binder or bitumen, which obtained by the partial distillation of crude petroleum, acts as a liquid binding material that binds and holds asphalt together and provides a smooth and flat surface for moving vehicles (Hashemian et al. 2014; Huan et al. 2011). In addition, bitumen is also often used as a coating and adhesive materials. It is also widely used in the construction of boats and waterproof vessels and as it is insoluble in water. In the hydraulic field, bitumen is needed for the construction of water tanks, dams, and bridges (Lv et al. 2014).

Recent studies have focused on changes in the mechanical strength of bitumen during the consolidation of bitumen with thermoplastic. Modified bitumenpolymers are widely used to improve the durability of asphalt mixtures. Cui et al. (2014) used a polymer modifier of PE, which can escalate the resilience of bitumen. PE blocks form particles that enforce as cross-links and polybutadiene chains all form a three-dimensional network and stabilize bitumen bonds, while PE shows elastomer behavior. The mechanical properties of bitumen will also change when reacting with PP by customizing the modified rheological properties of bitumen (Yuanita et al. 2017). The reduction in the flow rate and the escalation in the binder content show/reflect the increase in bonding viscosity that will drive the plastic flow in the mixture. These mixtures can make the strength of the bitumen higher and suitable for different applications.

However, the practical use of bitumen as a binder for mixing asphalt has been affected seriously due to the limitations of its chemical composition and structure. Water-induced damage and traffic load were the two main reasons for causing the damage, decomposition, and failure to function. In general, composite damage is divided into two, which namely are macro and microfractures (Yang et al. 2003). Micro-fractures caused by heat and mechanical fatigue is also a long-term problem with polymer adhesives (Nahar et al. 2014). If the micro-crack is not addressed, then a macro-crack will occur. Macro cracking involves the destruction of materials due to the impact (Jahromi et al. 2014). Regardless of the application, when cracks start to occur on polymeric materials, the integrity of the material structure is likely to be impaired (White et al. 2001). Macro damage requires a high cost of revamping. In order to solve this problem, the concept of self-self-healing was introduced.

Natural processes originally inspired self-healing materials. For example, blood flow to the fingers can stop itself from flowing (Garcia et al. 2010). There are two concepts in self-self-healing: the concept of autonomic and intrinsic (or non-autonomic) self-healing. This autonomic concept requires no stimulus (other than the formation of damage) for healing response, which delivers healing agents to compromised regions as soon as damage is inflicted (White et al. 2001). However, this study involved intrinsic self-healing, which requires some type of externally applied stimulus, involving materials capable of rectifying molecular and macro-scale damage through temporary local enhancement in the polymer chain. It can be achieved through reverse thermal reactions (Chuo \& Liu 2013; Zheng et al. 2013), hydrogen bonding (Bode 2012), ionomer coupling (Herbst et al. 2013), covalent bonding and coupling (Imato et al. 2012) and random infiltration (Rubinstein et al. 2015). Self-healing is intrinsically dependent on external stimuli such as heat energy and pH (Garcia 2014).

Self-healing in asphalt is viable because the features of bitumen in the asphalt itself are able to salvage when given energy or heat. For thermoplastic fillers into asphalt, thermoplastics can shift the mechanical features of the bitumen (Smith et al. 2014). Various studies on bitumenthermoplastic mixing have transformed the mechanical features of the material. To this day, there are limited studies about crack healing of bitumen with thermoplastic. This study focuses on the effect of thermoplastic fillers (PP and PE) on modified bituminous-polymer crack-healing reactions.

\section{EXPERIMENTAL PROCEDURES MATERIALS}

The $80 / 100$ penetration grade base bitumen was obtained from Cenco Sains, a local bitumen factory in Port Klang, Malaysia. Polypropylene (PP) ( $\bar{M} w$ of $67,000 \mathrm{~g} / \mathrm{mol})$ and polyethylene (PE) $(\bar{M} w$ of $4,000 \mathrm{~g} / \mathrm{mol})$ were obtained from Titanpro Chemicals made by Titan Petchem (M) Sdn Bhd. A continuous dense gradation of sand with a maximum particle size of $6 \mathrm{~mm}$ was used in the preparation of asphalt composite (from Kajang Rock Quarry Malaysia).

\section{PREPARATION OF ASPHALT COMPOSITES}

The first phase involves the production of modified bitumen-thermoplastic. Samples were prepared using a melt blending technique. The bitumen about $400 \mathrm{~g}$ was heated in the oven till fluid condition and polymer were slowly added, while the speed of the mixer was maintained at $120 \mathrm{rpm}$ and the temperature was kept at $160{ }^{\circ} \mathrm{C}$. The concentration of PP and PE, used, was 2, 4, 6 and $8 \%$ by weight of the blend. Mixing was continued for 1 hour before the modified bitumen was then sealed in containers covered with aluminum foil and stored for further testing.

The next phase involves the production of sandbitumen composites. A pre-calculated amount of dry sand and bitumen; with the proportion of $15 \mathrm{wt} \%$ bitumen and $85 \mathrm{wt}$. \% aggregates, were placed separately in preheated ovens at $170{ }^{\circ} \mathrm{C}$ for $2 \mathrm{~h}$, respectively. After this period, the bitumen (for control sample) or modified 
bitumen-thermoplastic and sand were heated to $170{ }^{\circ} \mathrm{C}$ and mixed in the mixer for about 3 min to obtain a hot mixture. The laboratory specimens were prepared in a steel mold (lubricated inner surfaces) with a dimension of $3 \times 4 \times 16 \mathrm{~cm}^{3}$ ASTM E647-00 (2000). A hammer (for Standard Proctor Test) was used for compaction of samples. The sample was left to cool to room temperature before being removed from the mold.

\section{MECHANICAL TESTING AND CHARACTERIZATION THREE POINT BENDING TEST (TPBT)}

Three-point bending was used to characterize asphaltthermoplastic behavior. Fundamental of asphaltthermoplastic fracture properties, identified as tensile strength was determined with two different samples, which were asphalt-PE and asphalt-PP with three different percentages of thermoplastic, respectively. Threepoint bend specimens were used for the experiments, simulation, and prediction according to the ASTM E64700 (2000) standard as in Figure 1. At least five specimens were carried out for each set of data.

\section{HEALING PROCESS}

After the sample was broken through the three-point bending test, the two broken or cracked samples were all placed in the mold and placed in the oven at the healing temperature, which is $160{ }^{\circ} \mathrm{C}$ for $60 \mathrm{~min}$. The mold with the sample was cooled to room temperature and then extracted the sample to see if the recovery percentage and tensile strength from the original strength and it will be repeated until three healing cycles. Figure 2 shows the schematic of the recovery process platform. The percentage recovery $\left(R_{E}\right)$ of the sample was calculated based on the average tensile strength, which can be described in (1).

$$
R_{E}=\frac{100 \times E_{\text {healed }}}{E_{\text {initial }}}
$$

\section{CHARACTERIZATION}

Fourier transform infrared (FTIR) spectroscopy used in this study is the Spectrum ASCII PEDS 400 ATR Spectrometer from Perkin Elmer. The spectra were recorded at room temperature with an average signal of 64 scans at intervals of 2 and $16 \mathrm{~cm}^{-1}$ resolutions in the $4000-500 \mathrm{~cm}^{-1}$ infrared spectrum. Meanwhile, the dynamic mechanical properties of the samples were determined using a dynamic mechanical thermal analyser (DMTA) of TA Instruments Thermal Analysis, DMA 2980. Measurements were performed in the single cantilever bending mode. The spectra were collected from room temperature to $180{ }^{\circ} \mathrm{C}$ at a heating rate of $2 \mathrm{~K} / \mathrm{min}$ and a single frequency of $1.0 \mathrm{~Hz}$.
Surface morphological studies and cracking processes of samples were performed using Optical Microscope. The microscope model used is the Axiolab A450909 Image Analyzer with Zeiss camera. The crosssectional fracture surfaces from the fatigue tests of the bulk epoxy specimens were examined using a Scanning electron microscope (SEM). The fracture surfaces were first sputter-coated with a thin layer of gold to prevent charging. Conventional secondary electron imaging conditions, with an accelerating voltage of $15 \mathrm{kV}$, were employed.

\section{RESULTS AND DISCUSSION}

\section{FTIR ANALYSIS}

The concept of intrinsic crack healing depends on the random infiltration or diffusion of molecules in the thermoplastic to coat the cracked surface. FTIR-ATR was used to ensure that no interactions or chemical bonds are formed between the linear thermoplastic (PP or PE) and bitumen. Bitumen consists of $95 \%$ carbon and hydrogen ( $\pm 87 \%$ carbon and $\pm 8 \%$ hydrogen $)$, and up to $5 \%$ sulphur, $1 \%$ nitrogen, $1 \%$ oxygen and 2000 ppm metals (Haseeb et al. 2017).

Based on Figure 3, the FTIR spectra for bitumen showed that the stretching vibrations of $-\mathrm{CH}_{2}$ occurred between 2918 and $2850 \mathrm{~cm}^{-1}$. The next important absorption peaks are $\mathrm{C}-\mathrm{O}$ bond that attached with $\mathrm{C}=\mathrm{C}$ which known as $\mathrm{C}=\mathrm{O}$ conjugated at $1653 \mathrm{~cm}^{-1}$ and $\mathrm{C}=\mathrm{C}$ (aromatic) bond at $1596 \mathrm{~cm}^{-1}$ which represents the stretching vibration of the aromatic hydroxyl. Lower peaks of absorption at 1456 and $1372 \mathrm{~cm}^{-1}$ are referred to bending $\mathrm{CH}_{2}$ and $\mathrm{CH}_{3}$, respectively. The $\mathrm{C}=\mathrm{C}$ aromatic of the benzene ring is detected at $1290 \mathrm{~cm}^{-1}$ and the stretching vibration of sulfoxide bond, $\mathrm{S}=\mathrm{O}$ is at 1026 $\mathrm{cm}^{-1}$. The lowest peak at $859-723 \mathrm{~cm}^{-1}$ is the $\mathrm{CH}$ benzene out of plane. All tested samples were moisture-free as indicated by the absence of a free water molecule peak of $-\mathrm{OH}$ at $3400 \mathrm{~cm}^{-1}$.

Figure 4(a) shows the FTIR spectra for PP. The spectra on 2950, 2918, and $2836 \mathrm{~cm}^{-1}$ describe $\mathrm{CH}$ stretch while the peak on 1456 and $1376 \mathrm{~cm}^{-1}$ are specific spectra of PP containing $\mathrm{CH}_{2}$ deformation and symmetric $\mathrm{CH}_{3}$ deformation. The spectra on 998,974 , and $842 \mathrm{~cm}^{-1}$ show isotactic PP band. Finally, the spectrum on the peak 1167 $\mathrm{cm}^{-1}$ indicates the $\mathrm{C}-\mathrm{C}$ bending which is the backbone of PP. Meanwhile, Figure 4(b) shows 4 major peaks in PE spectrum. FTIR show peak at $720 \mathrm{~cm}^{-1}$ that is $\mathrm{CH}_{2}$ rocking vibration while $1460 \mathrm{~cm}^{-1}$ is $\mathrm{CH}_{2}$ scissoring vibration. On 2850 and $2920 \mathrm{~cm}^{-1}$ both show $\mathrm{C}-\mathrm{H}$ symmetrical stretching vibration.

In comparison between the spectra in Figures 3, 4(a), and 4(d), there is no chemical reaction between bitumenPP and bitumen-PE as all peaks in both chemicals appear 
in the mixture spectrum as in Figure 4(c) and 4(d). Again, this proves that the addition of linear thermoplastics to the bitumen does not alter the chemical structure of the material with no new bond formation is formed specifically between the two materials.

\section{GLASS TRANSITION TEMPERATURE $\left(T_{g}\right)$}

DMTA analysis was conducted to determine the value of glass transition temperature $\left(T_{g}\right)$ and the effect of the linear thermoplastic on the thermomechanical properties of the bitumen-thermoplastic mixture. $T_{g}$ was defined as the maximum in tan delta. Figure 5 shows the DMTA curves for the bitumen, linear thermoplastic (PP and PE) and bitumen-thermoplastic mixture. From Figure 5(a) and 5(b) we can see that PE and PP have higher $T_{g}$ compared to bitumen $\left(112^{\circ} \mathrm{C}\right)$ which is 158 and $174{ }^{\circ} \mathrm{C}$, respectively. From the mixing of bitumen-thermoplastic blend, the $T$ of mixtures with healing agent has been shifted. DMTA curves of bitumen-PE and bitumen-PP produced a broad peak, which is at 136 and $127^{\circ} \mathrm{C}$. Furthermore, the shifty of the $T_{g}$ in bitumen-thermoplastic mixture is due to the addition of thermoplastic that will increase the softening point; thus, increase the $T_{g}$ of the sample.

Furthermore, $T_{g}$ from the maximum value of Tan $\delta$ has been used as a reference for the healing process. Based on this result, a temperature of $160{ }^{\circ} \mathrm{C}$ is chosen for the healing process which is near/higher than the $T_{g}$ of the bitumen-thermoplastic mixture. This healing temperature is representing as a $T_{g}$ of the matrix resin; in which the transition in the amorphous regions (from the semi-crystalline solid resin) between the glassy and rubbery state occurs. At this temperature, portions of the molecules would simply absorb the energy by momentarily deforming or stretching and can improve its flexibility. It is postulated that this effect can improve the diffusion of healing agent through the reptation process within the matrix bitumen.

\section{THE EFFECTIVENESS SELF-HEALING OF THERMOPLASTIC MODIFIED ASPHALT}

Studies on the effectiveness of crack healing are conducted through three-point bending test. Compact tension testing has been employed for the assessment of healing performance. It can provide a quantitative measurement of the healing efficiency by measuring the recovery of tensile strength between the standard and modified bitumen (with thermoplastic) after repeated healing.

It is observed that the tensile strength of sample significantly increases; with the increases in weight percentage of linear thermoplastic (from 2 to $6 \%$ by weight) in bitumen (Figure 6). This increase is due to the increasing of the toughness and the strength of bitumen mixture where the pressure applied can be evenly distributed throughout the sample. However, there is a decrease in the value of tensile strength with mixing of more than $8 \%$ by weight of thermoplastic in bitumen. At this stage, uneven mixtures are formed where thermoplastic causing uneven scattering and forming clumps within the bitumen mixture.

The crack-recovery of the asphalt mixture containing bitumen-thermoplastic was studied and is summarised in Figures 7 and 8 . Figure 7 shows the tensile strength for the mixture of asphalt (with 4,6 , and 8 wt. \% of PE) as a function of multiple healing cycles. A healing temperature of $160^{\circ} \mathrm{C}$ with a healing time of $1 \mathrm{~h}$ was used for each healing cycle before being left to cool down to 25 ${ }^{\circ} \mathrm{C}$ at a rate of $2 \mathrm{~K} / \mathrm{min}$. The percentage recovery $\left(\mathrm{R}_{\mathrm{E}}\right)$ of the sample was calculated based on the average of tensile strength (1). It was found that asphalt with $6 \%$ by weight of PE has a higher percentage recovery followed by 4 and $8 \%$, with 91,85 , and $75 \%$ of average percentage recovery, which taken from the average of all three- healing cycle. For the second and third healing cycles, it was observed that $6 \%$ of PE still achieved the highest percentage recovery followed by 4 and $8 \%$. It shows that $6 \%$ of PE is the best ratio to mix with asphalt. Meanwhile, Figures 8 shows a plot of tensile strength in the asphalt-PP mixture as a function of multiple healing cycles. Within the third healing cycle, we can see that $4 \%$ by weight PP has the highest percentage recovery compared with mixture consist of 6 and $8 \%$ by weight of PP. The result of 95,91 and $93 \%$ of percentage recovery were recorded from the average of all three-healing cycles.

Overall, data for three impact/heal cycles showed the effect of multiple healing events on healing performance (Figures $7 \& 8$ ). Healing was achieved through the possibility of random molecule diffusion or/and volumetric thermal expansion of healing agents within the matrix. This crack healing process was described schematically as shown in Figure 9. This healing agent (thermoplastic) become mobile above the minimum healing temperature for crack closure through random molecule diffusion. Zhang and $\mathrm{Li}$ (2016) reported on the theory of crack healing via molecular interdiffusion in polymeric materials involving the processes of surface rearrangement, wetting, diffusion, and randomization that took place across the micro-fine crack. These crack-healing systems are time and temperature-dependent; and occurred via the free volume, void closure, surface interaction and molecular entanglement between the damaged faces. In addition, the 'dangling chains' concept is described as chain segments where one end is not connected to the network and exhibits a segmental inter-diffusion for micro-crack recovery (Blaiszik et al. 2010). Meanwhile, in the 'brick and mortar' concept, as heating the system, the healing agent (act as a brick) will undergo volumetric thermal expansion and viscous flow above its melting point in 
excess of epoxy expansion (act as a mortal) (Meure et al. 2012). Upon cooling, the formation and precipitation of polymer crystals occur and subsequently act to cover the cracked surface area and restore the mechanical strength of the material.

In addition, based on the result of percentage recovery, we can see that asphalt modified with PP has higher percentage recovery than the asphalt-PE mixture. This may be due to the prolongation of the PP chain which will provide more effect on entanglement during fracture recovery as well as provide additional strain on the fracture recovery area. Although there was an improvement in percentage recovery, the reduction in healing efficiency was recorded after exposure to repeated healing. It is suggested that a reduction in healing efficiency after repeated healing cycles is mainly due to the physical aging effect. Linear polymer diffusion is closely related to the ability of molecular structure to move, diffuse, or expand based on the free volume/space that existed within the matrix resin. The gradual rearrangement of molecular chains can occur during aging (or healing) at/or above the $T_{g}$ which enabled the packing of the molecules to be enhanced during its approach towards the equilibrium glassy state (Rapp et al. 2019). This is related to the reduction in the fraction of free volume from the relaxation of the network through the chain conformation and thus restricts the rate of reptation for the diffusion/ expansion of the healing agent.

\section{MORPHOLOGY STUDY}

Crack healing occurs when an energy stimulus in the form of temperature is applied to a cracked area. After completion of the impact tests on the sample of bitumen and bitumen-polymers in two self-healing cycles, the recovery process was observed. Figure 10 shows changes to the sample of bitumen-PE; before and after fracture recovery. The sample was then broken by the impact test (Figure 10(b)). Subsequently, the sample undergoes a crack-healing process at $T_{g}, 160{ }^{\circ} \mathrm{C}$. Figure $10(\mathrm{c})$ shows that the two fractured parts were successfully restored. The impact of this fracture recovery can be clearly seen through the optical micrograph diagram where the cracked surface is filled with healing agent or thermoplastic to restore the strength of the sample. Furthermore, Figure 11 shows the fracture recovery process through SEM images. It can be seen that the impact of the fracture is reduced after $30 \mathrm{~min}$ of healing recovery and almost completely gone after 60 min of recovery. It can be concluded that by using this concept of crack recovery, we manage to repair the fracture of the bitumen-thermoplastic mixture.

\section{CONCLUSION}

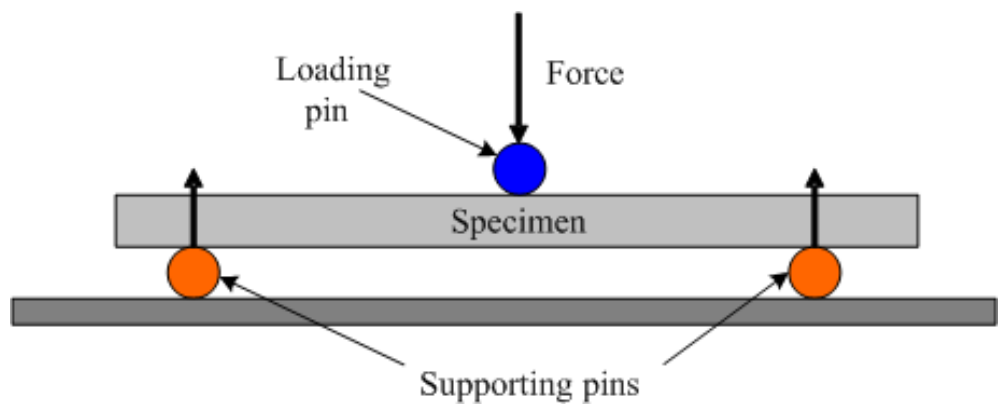

FIGURE 1. Three-point bending illustration

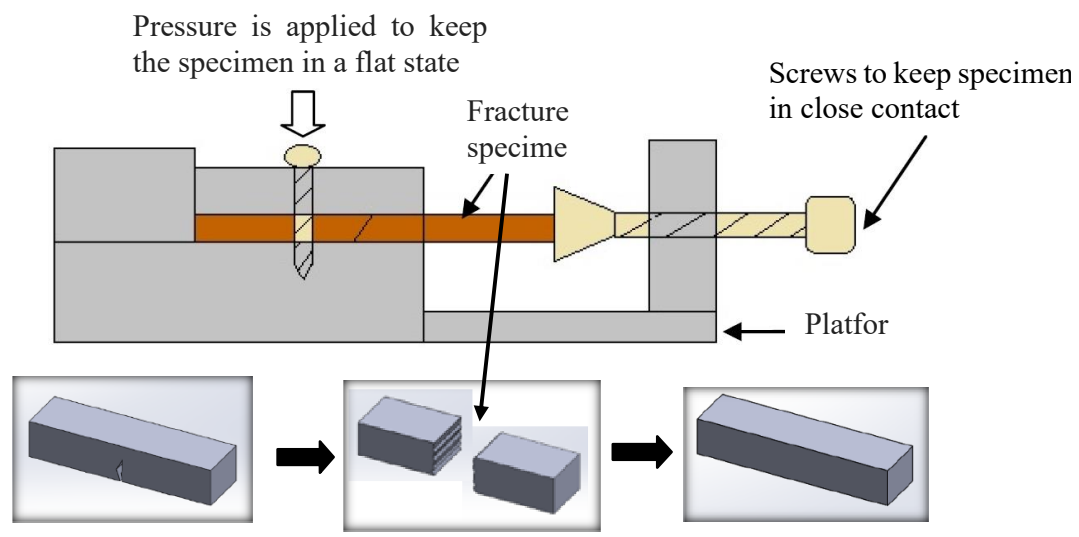

FIGURE 2. Schematic of the recovery process platform 


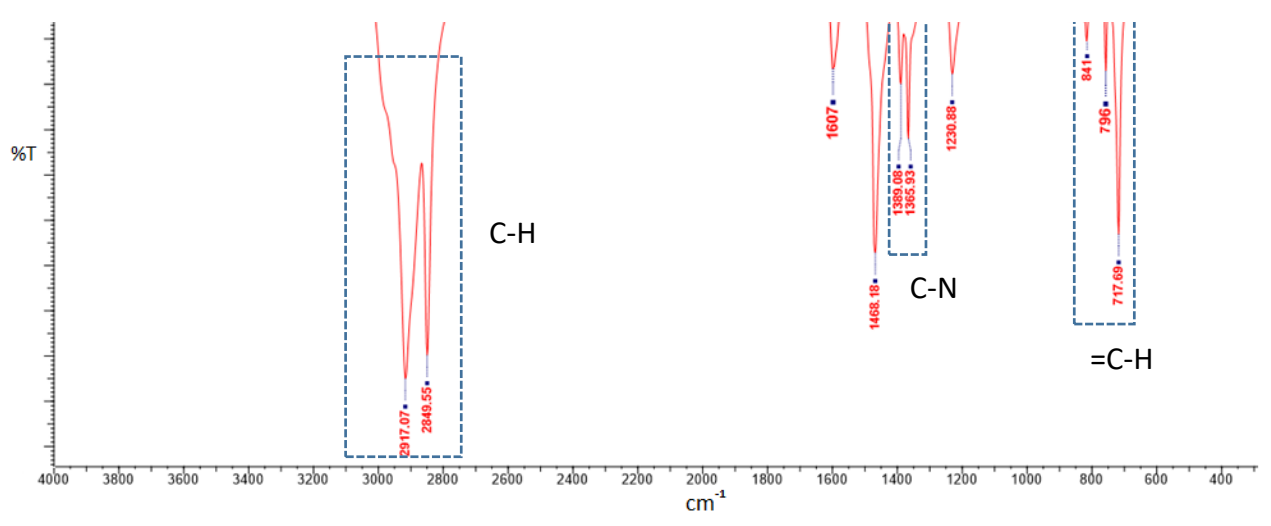

FIGURE 3. FTIR analysis spectra with a range of $4000-400 \mathrm{~cm}^{-1}$ of bitumen $80 / 100$

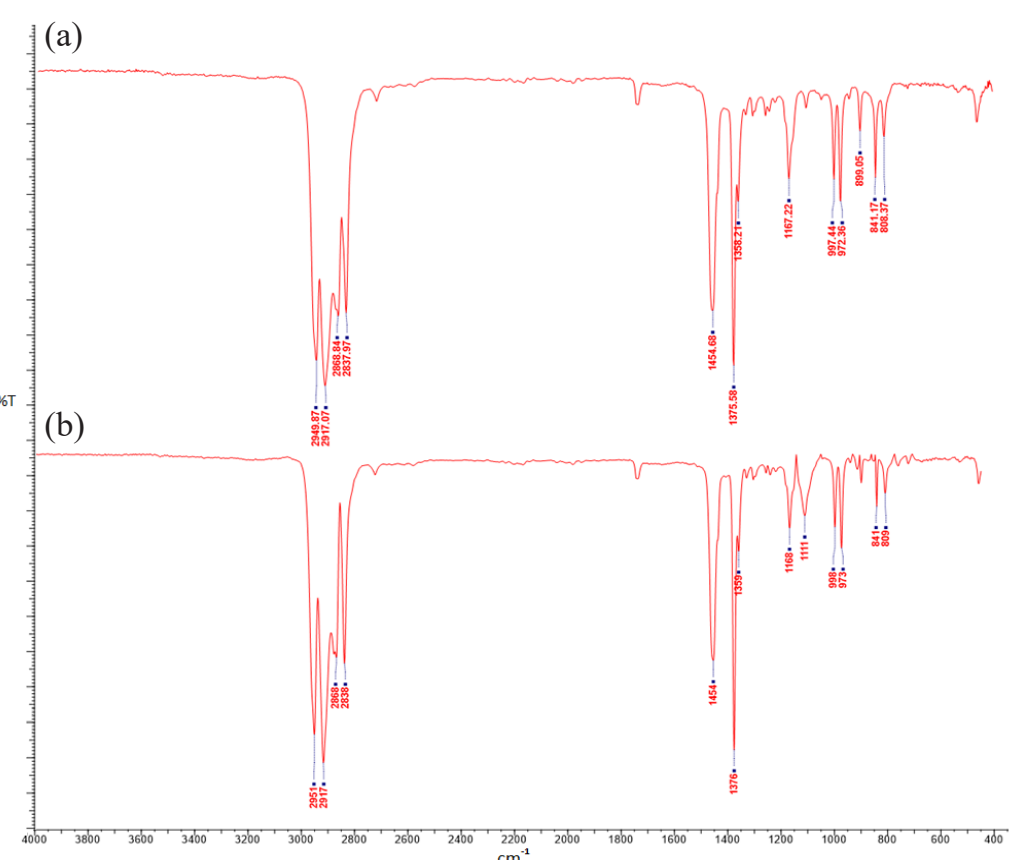

(c)

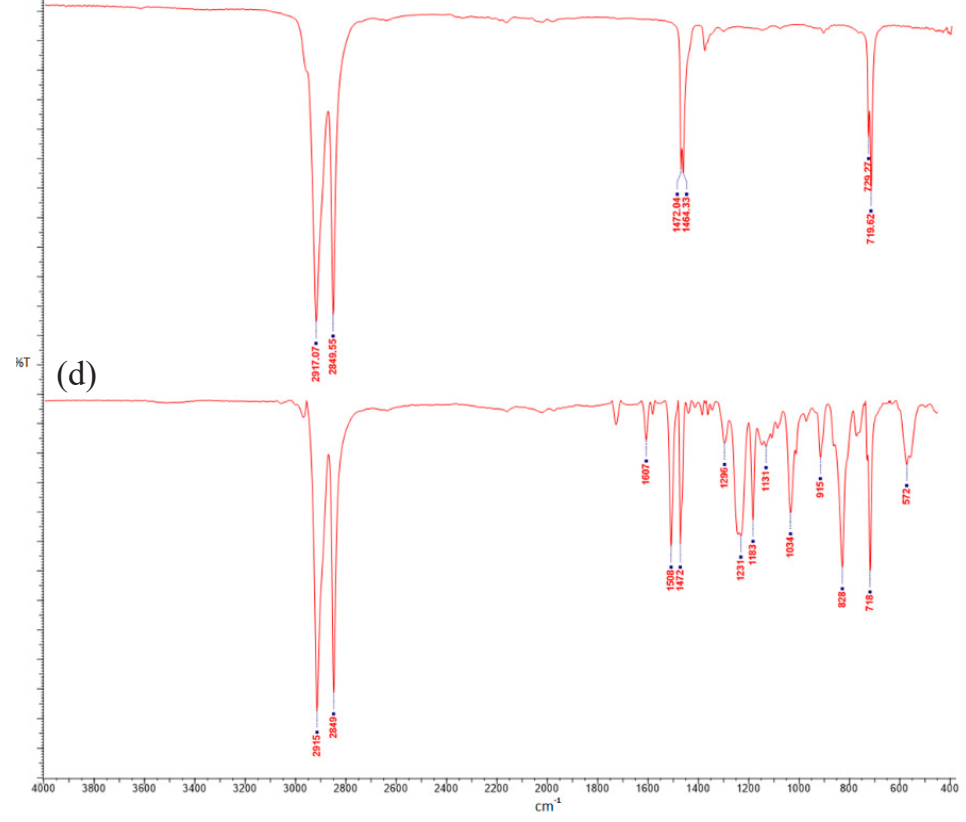

FIGURE 4. Spectra of FTIR analysis with a range of 4000-400 $\mathrm{cm}^{-1}$ for (a) PP (b) bitumen-PP, (c) PE and (d) bitumen-PE 

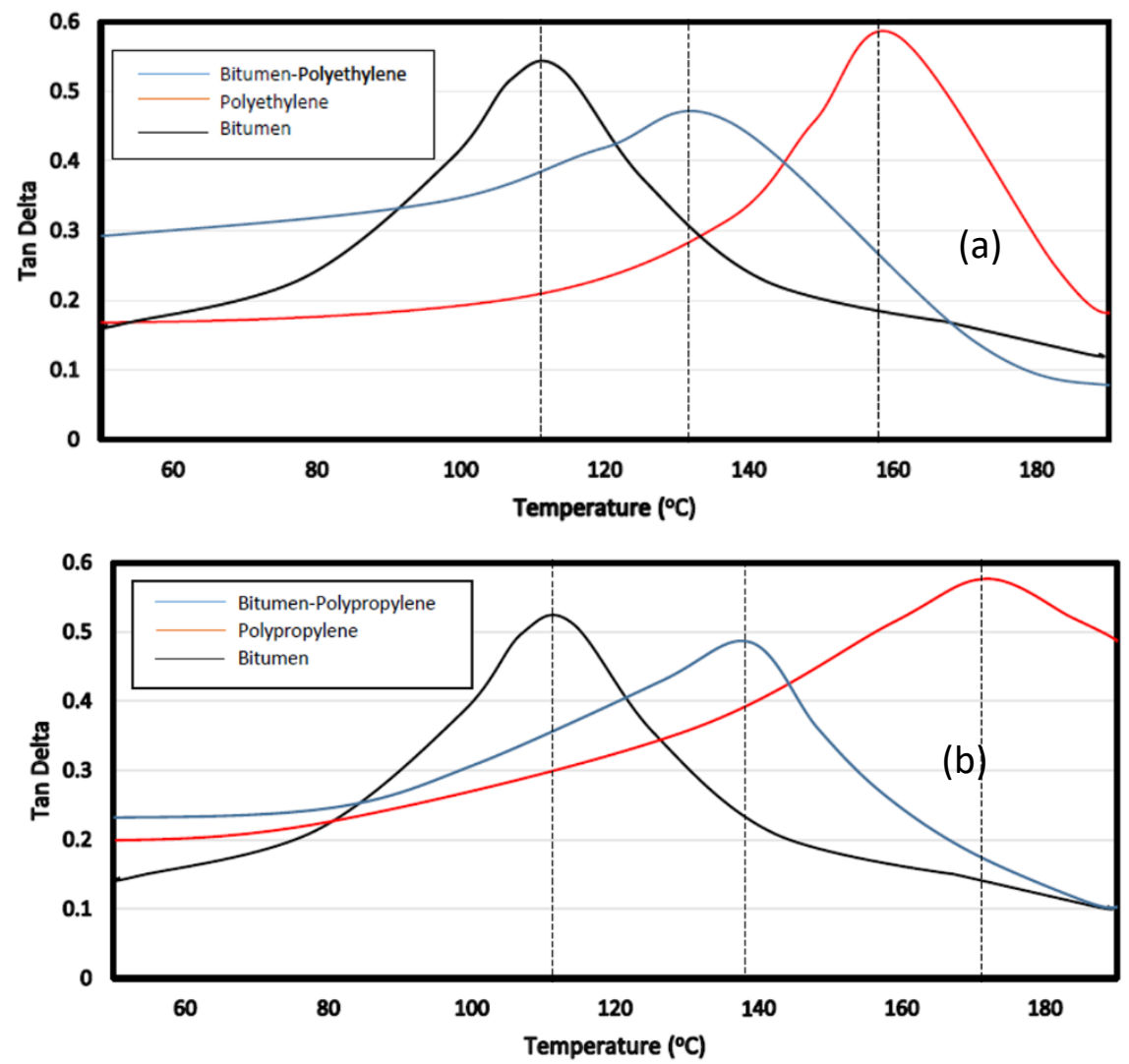

FIGURE 5. Loss tangent as a function of temperature plotted for bitumen, PE, PP, (a) bitumen-PE and (b) bitumen-PP

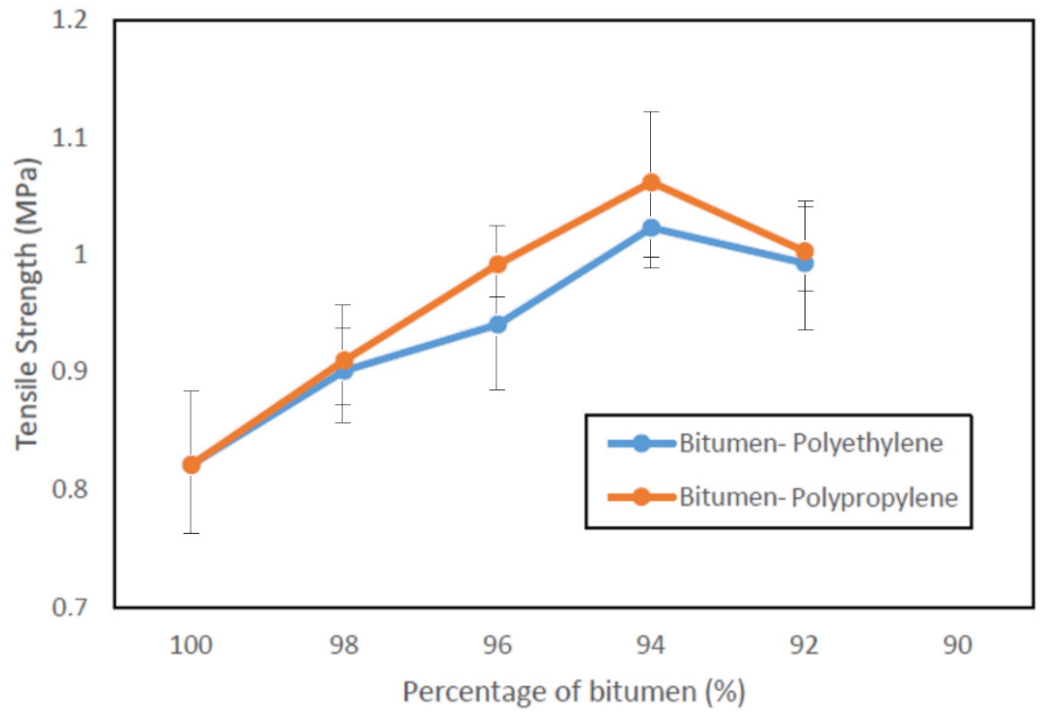

FIGURE 6. Graph of change in tensile strength from three-point bending test for the mixture of bitumen-PP and bitumen-PE 


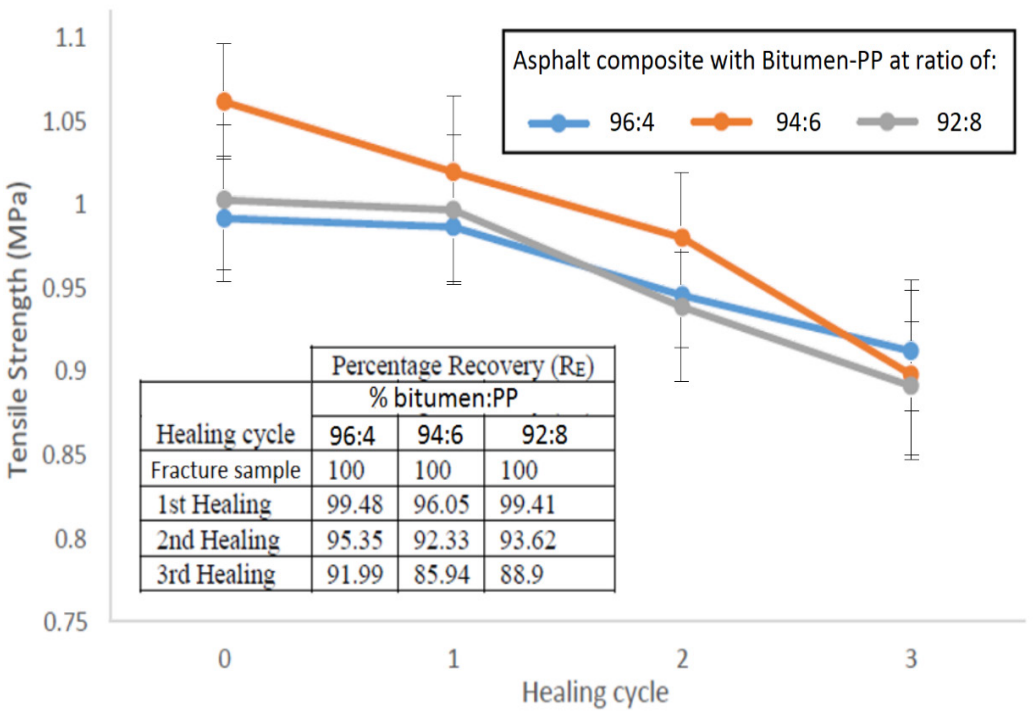

FIGURE 7. The tensile strength for the mixture of asphalt (with 4, 6 and 8 wt. \% of PP) as a function of multiple healing cycle. Inset: The percentage recovery $\left(\mathrm{R}_{\mathrm{E}}\right)$ after healing events as a function of the varying healing agent. The samples were healed at $160{ }^{\circ} \mathrm{C}$ for 60 min in each healing cycle

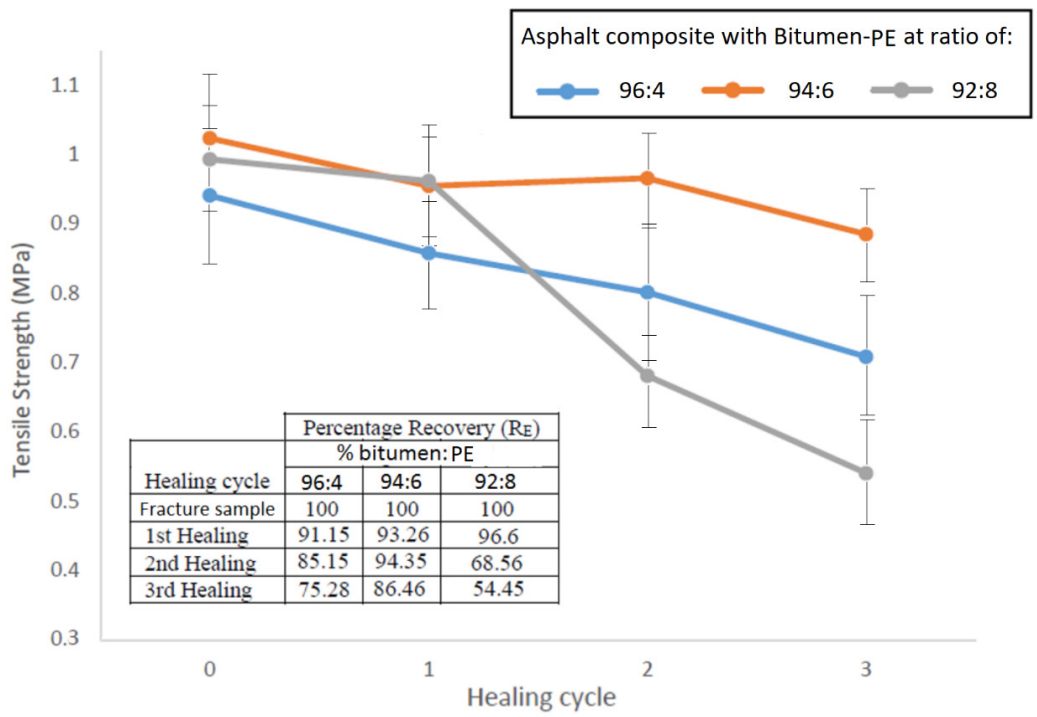

FIGURE 8. The tensile strength for the mixture of asphalt (with 4,6 and 8 wt. $\%$ of PE) as a function of multiple healing cycle. Inset: The percentage recovery $\left(R_{E}\right)$ after healing events as a function of the varying healing agent. The samples were healed at $160^{\circ} \mathrm{C}$ for $60 \mathrm{~min}$ in each healing cycle 
(a)

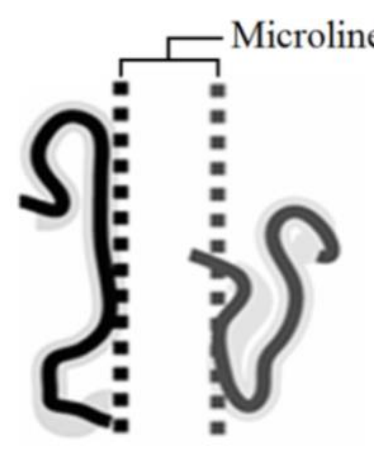

(b)

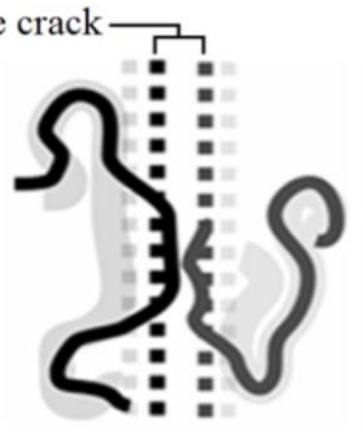

(c)

(d)

FIGURE 9. Schematic illustration of mechanisms involved in selfhealing via molecular inter-diffusion based on (a) rearrangement of surface approach (b) wetting of the surface (c) low level diffusion between surface and (d) diffusion, equilibration, and randomization process
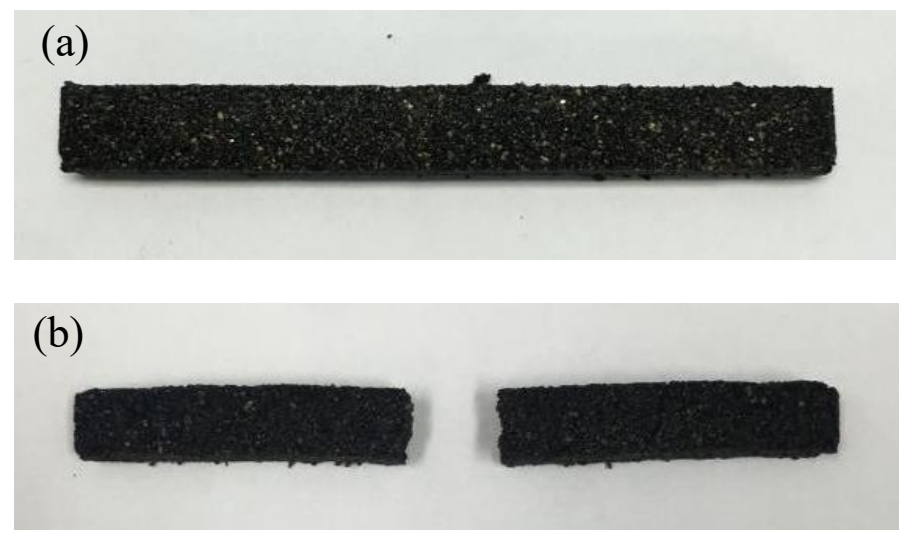

(c)
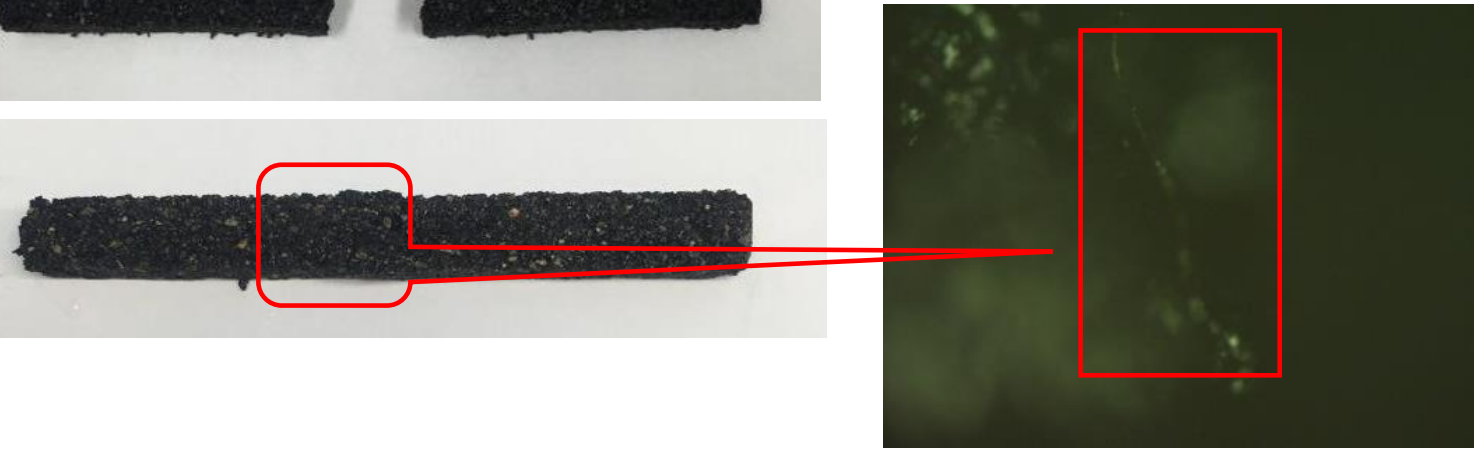

FIGURE 10. Micro fracture/cracking micrograph on the surface of (a) the mixture of asphalt with 6 wt. \% of PP during the impact test (b) before and (c) after the healing process 


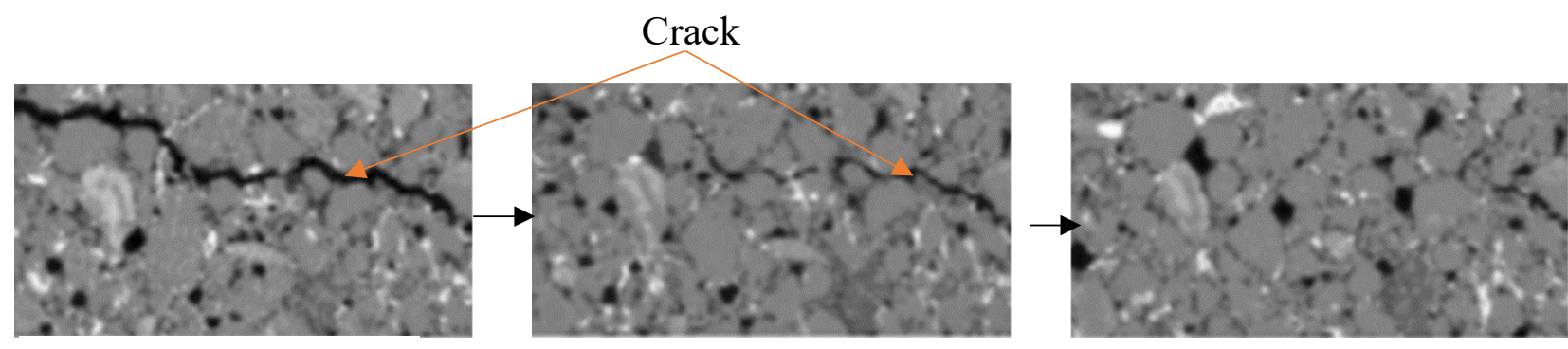

Sample after

30 min of healing

(Half crack has been
60 min of healing

(Crack has fully recovered)

FIGURE 11. SEM for healing crack of asphalt with $6 \mathrm{wt}$. \% of PP

Studies on bitumen crack-healing systems using thermal stimuli were carried out and PP was selected as the crack-healing agent with the highest repair percentage compared to non-thermoplastic and bitumen-PE bitumen. This crack-healing system can only be performed at the minimum self-healing temperature above $T_{g}$. The effectiveness of crack healing is determined by measuring the return of mechanical strength after going through a cycle of repeated crack healing to the original strength. Within the third healing cycle, asphalt-PP mixture (with 4,6 , and $8 \%$ by weight PP) produced the highest average percentage recovery, which is at 95,91 , and $93 \%$ in each cycle. In the healing process, asphalt-PP mixture underwent a random molecule diffusion and/or volumetric thermal expansion of the healing agent to close and restore the fracture area and bring the crack surface into contact. The crack-healing process was proven through the surface and cross-section resin morphology analyses using microscopy optic and SEM. Overall, studies on the effectiveness of crack healing through the use of different thermoplastic as a healing agent for enhancement of the mechanical properties of bitumen have been proved.

\section{ACKNOWLEDGEMENTS}

The authors acknowledged the financial support of this study from the Government of Malaysia through the grant number of GGP-2017-086. The authors also wish to thank the Center for Advanced Materials and Renewable Resources, Faculty of Science and Technology and the Department of Mechanical and Engineering, Faculty of Engineering and Architecture, National University of Malaysia for the facilities and support of this project.
ASTM E647. 2000. Standard Test Method for Measurement of Fatigue Crack Growth Rates. American Society for Testing and Materials (ASTM).

Blaiszik, B.J., Kramer, S.L., Olugebefola, S.C., Moore, J.S., Sottos, N.R. \& White, S.R. 2010. Self-healing polymers and composites. Annual Review of Materials Research 40: 179-211.

Bode, T.A. 2012. An analysis of the impacts of temperature segregation on hot mix asphalt. University of NebraskaLincoln. MS Thesis (Unpublished).

Chuo T.W. \& Liu, Y.L. 2013. Self-healing polymers based on thermally reversible Diels-Alder chemistry. Polymer Chemistry 4(7): 2194-2205.

Cui, S., Blackman, B.R., Kinloch, A.J. \& Taylor, A.C. 2014. Durability of asphalt mixtures: Effect of aggregate type and adhesion promoters. International Journal of Adhesion and Adhesives 54: 100-111.

Garcia, S.J. 2014. Effect of polymer architecture on the intrinsic self-healing character of polymers. European Polymer Journal 53: 118-125.

Garcia, A., Schlangen, E. \& Van de Ven, M. 2010. Two ways of closing cracks on asphalt concrete pavements: Microcapsules and induction heating. Key Engineering Materials 417: 573-576.

Hashemian, L., Kavussi, A. \& Aboalmaali, H.H. 2014. Application of foam bitumen in cold recycling and hydrated lime in airport pavement strengthening. Case Studies in Construction Materials 1: 164-171.

Herbst, F., Döhler, D., Michael, P. \& Binder, W.H. 2013. Self-healing polymers via supramolecular forces. Macromolecular Rapid Communications 34(3): 203-220.

Huan, Y., Jitsangiam, P. \& Nikraz, H. 2011. Effects of active filler selection on foamed bitumen mixture in Western Australia. Applied Mechanics and Materials 90: 457-465. Imato, K., Nishihara, M., Kanehara, T., Amamoto, Y., Takahara, REFERENCES 
A. \& Otsuka, H. 2012. Self-healing of chemical gels cross-linked by diarylbibenzofuranone-based trigger-free dynamic covalent bonds at room temperature. Angewandte Chemie 51(5): 1138-1142.

Jahromi, S.G., Vossough, S., Andalibizade, B. \& Smith, B. 2014. Fatigue and low temperature fracture in bitumen mastic. Petroleum Science and Technology 32(3): 267-273.

Lv, D.W., He, J. \& Sun, X.L. 2014. Indoor study on road performance of macromolecule polymer bitumen waterproof and cohesive layer (PCMA). Advanced Materials Research 912-914: 172-177.

Meure, S., Varley, R.J., Wu, D.Y., Mayo, S., Nairn, K. \& Furman, S. 2012. Confirmation of the healing mechanism in a mendable EMAA-epoxy resin. European Polymer Journal 48(3): 524-531.

Nahar, S.N., Schmets, A.J.M., Scarpas, A. \& Schitter, G. 2014. Microstructural changes in bitumen at the onset of crack formation. European Polymer Journal 56: 17-25.

Rapp, G., Tireau, J., Bussiere, P.O., Chenal, J.M., Rousset, F., Chazeau, L., Gardette, J.L. \& Therias, S. 2019. Influence of the physical state of a polymer blend on thermal ageing. Polymer Degradation and Stability 163: 161-173.

Rubinstein, A., Moradov, D., Shifrin, H., Harel, E., NadlerMilbauer, M., Weinstock, M. \& Srebnik, M. 2015. The anti-inflammatory activity of a novel fused-cyclopentenone phosphonate and its potential in the local treatment of experimental colitis. gastroenterology research and practice. Gastroenterol. Res. Pract. 2015: Article ID. 939483.

Smith, B., Jahromi, S.G., Vossough, S. \& Andalibizade, B. 2014. Fatigue and low temperature fracture in bitumen mastic. Petroleum Science and Technology 32(3): 267-273.

White, S.R., Sottos, N.R., Geubelle, P.H., Moore, J.S. \& Kessler,
M.R. 2001. Autonomic healing of polymer composite. Nature Research Journal 409: 794-797.

Yang, P., Cong, Q. \& Liao, K. 2003. Application of solubility parameter theory in evaluating the aging resistance of paving asphalts. Petroleum Science and Technology 21(11-12): 1843-1850.

Yuanita, E., Hendrasetyawan, B.E., Firdaus, D.F. \& Chalid, M. 2017. Improvement of polypropylene (PP)-modified bitumen through lignin addition. IOP Conference Series: Materials Science and Engineering 223: 012028.

Zhang, P. \& Li, G. 2016. Advances in healing-on-demand polymers and polymer composites. Progress in Polymer Science 57: 32-63.

Zheng, Z., Du, P., Liu, X., Wang, X., Joncheray, T. \& Zhang, Y. 2013. Synthesis and characterization of linear self-healing polyurethane based on thermally reversible diels-alder reaction. RSC Advances 3(35): 15475-15482.

Department of Chemical Sciences

Faculty of Science and Technology

Universiti Kebangsaan Malaysia

43600 UKM Bangi, Selangor Darul Ehsan

Malaysia

*Corresponding author; email: wan.naqiuddin94@gmail.com

Received: 15 October 2019

Accepted: 18 June 2020 